J. Lake Sci.(湖泊科学), 2009, 21(4): 587-593

http://www.jlakes.org. E-mail: jlakes@niglas.ac.cn

(C2009 by Journal of Lake Sciences

\title{
基于水热平衡模型的青海湖水位变化趋势预测*
}

\author{
董春雨 ${ }^{1}$, 王乃昂 ${ }^{1}$, 李卓仑 ${ }^{1}$, 杨 萍 ${ }^{1,2}$ \\ (1: 兰州大学资源环境学院，兰州 730000) \\ (2: 青海师范大学生命与地理科学学院, 西宁 810008)
}

摘 要: 近几十年来, 随着气候干暖化, 以青海湖为代表的我国内陆湖泊水位持续下降, 生态环境问题日益突出, 备受世人关 注. 运用改进的水热平衡模型预测了 2050 年以前青海湖逐年的湖面蒸发量, 并运用多元线性回归的方法估算出流域未来径流 量的变化, 最终通过水量平衡的方式对 2050 年以前青海湖水位的变化趋势进行了定量预测. 预测表明未来几十年内, 青海湖 水位会经历先相对稳定再继续下降的过程，2020 年以前青海湖水位会相对稳定在 $3192.7 \mathrm{~m}$, 之后会继续下降，到 2050 年约下 降到 3191.22m，总体上 2010-2050 年青海湖水位下降趋势将有所缓和.

关键词: 青海湖; 水位变化; 水热平衡模型; 预测

\section{Forecast of lake level in Lake Qinghai based on energy-water balance model}

\author{
DONG Chunyu ${ }^{1}$, WANG Naiang ${ }^{1}$, LI Zhuolun ${ }^{1} \&$ YANG Ping ${ }^{1,2}$ \\ (1: College of Earth and Environmental Science, Lanzhou University, Gansu 730000, P.R.China) \\ (2: College of Life and Geography Science, Qinghai Normal University, Xining 810008, P.R.China)
}

\begin{abstract}
Water level in Lake Qinghai, a representative inland lake in northwest China, is declining rapidly under the influence of climatic change. At the same time, the environmental problem becomes more serious. It has arrested many people's attentions. In this paper, the stream flows for period until the year of 2050 are estimated by multiply linear regression and the trends of the water level are forecasted based on an improved model of hydrologic and energy balance. The prediction indicates that the water level would keep steadily about $3192.7 \mathrm{~m}$ before the year of 2020 , and then continues to decline. It would drop to $3191.22 \mathrm{~m}$ in 2050 . Changes of the water level in Lake Qinghai would become alleviative in the next several decades of 2010-2050.
\end{abstract}

Keywords: Lake Qinghai; water level change; model of hydrologic and energy balance; forecast

内陆湖泊是我国西北地区水资源的重要组成部分. 近些年来，随着气候干暖化，以及人类不合理的 开发利用，导致我国西北地区许多内陆湖泊不断退缩以至消亡，如我国西北的罗布泊、玛纳斯湖、艾比 湖等. 伴随着湖泊水位下降与湖泊面积收缩，湖滨地区发生植被退化、土地沙化、水质恶化，给当地居民 生活及工农业生产造成了严重的影响. 由于西北地区生态平衡比较脆弱，一旦遭受破坏，很难恢复. 从 这个意义上讲, 开展我国西北地区内陆湖泊的退缩过程分析, 并在此基础上探讨在未来气候变化情景下 我国西北内陆湖泊水位水量变化趋势，是一项非常重要、具有前瞻性的工作，对于合理开发、利用我国 西北地区的湖泊资源具有指导意义 ${ }^{[1-3]}$. 目前，国内外大量学者已经开始围绕我国西北地区湖泊退缩及变 化趋势预测开展研究工作, 并有很大进展 ${ }^{[4-7]}$.

据研究, 我国西北地区的气候当前正面临着由暖干向暖湿转型 ${ }^{[8-9]}$. 随着气候转型, 未来一段时期内 以青海湖为代表的我国西北内陆湖泊水位水量的变化情况, 成为一个需要迫切解决的问题. 以往学者多 是通过水量平衡的方法对湖泊水位变化进行定性的预测，如能对该方法进行一定的改进，定量预测湖泊

* 高等学校博士点基金项目(20050730030)、国家自然科学基金项目(50879033)和教育部重点项目(107107)联合资助. 2008-09-02 收稿; 2008-12-15 收修改稿. 董春雨, 男, 1986 年生, 硕士研究生; E-mail: dongchy04@1zu.cn. 
水位的变化, 无疑会更有现实意义. 水热平衡模型是建立在流域水量平衡和表面能量平衡的基础之上的, 以往都被用来重建古降水量 ${ }^{[10-13]}$, 是目前较为精确的估算古降水量的方法, 目前尚没有人将此模型应用 于湖泊水位水量变化趋势预测, 笔者对这一工作进行了尝试. 本文对水热平衡模型进行了改进, 使其更 适合青海湖地区. 最后, 通过改进的水热平衡模型, 定量估算青海湖未来几十年内水位变化趋势.

\section{1 研究区概况和数据资料}

\section{1 青海湖流域概况}

青海湖(图 1)是我国最大的内陆咸水湖, 位于青海省东北部, 是一个四周群山环绕的封闭式内陆盆地, 南傍 青海南山, 北靠大通山, 东临日月山. 湖区地势西北高、东南低, 海拔范围 3194-5174m, 流域总面积 $29660 \mathrm{~km}^{2}$. 其中湖面面积 $4377 \mathrm{~km}^{2}$, 东西长约 $106 \mathrm{~km}$, 南北宽约 $63 \mathrm{~km}$, 容积 $715.93 \times 10^{8} \mathrm{~m}^{3}$, 平均水深 $17.17 \mathrm{~m}^{[14]}$.

青海湖区多年平均气温 $-0.7^{\circ} \mathrm{C}$, 并呈南高北低的分布趋势. 湖区降水多年平均值为 $319-395 \mathrm{~mm}$, 周 围山区年降水量大于 $400 \mathrm{~mm}$, 降水量分布特点为湖心向湖周山区递增. 5-9 月降水量占全年的 $85 \%-89 \%$. 降水量年际变化较小, 变差系数 $C v$ 值在 $0.13-0.25$ 之间. 多年平均蒸发量约 $800-1100 \mathrm{~mm}$, 湖盆蒸发量大 于山丘区. 蒸发量年内分配不均, 年际变化较小, 变差系数 $C v$ 值在 0.10-0.15 之间 ${ }^{[15-16]}$.

青海湖流域河网呈明显的不对称分布，西北部河网发育，径流量大; 东南部河网稀疏，多为季节性 河流，且径流量小. 主要河流有布哈河、沙柳河、哈尔盖河、乌哈阿兰河和黑马河. 径流年内分配很不均 匀, 5-9 月径流量占全年的 $85 \%$ 以上. 径流年际变化大, 年最大值与最小值比值达 5.5 , 个别河流可达 25.9 . 由于湖区复杂多变的地质地貌及生态环境条件, 植被类型较为复杂多样, 表现为温性植被与高寒植被共 存的分布格局 ${ }^{[15]}$.

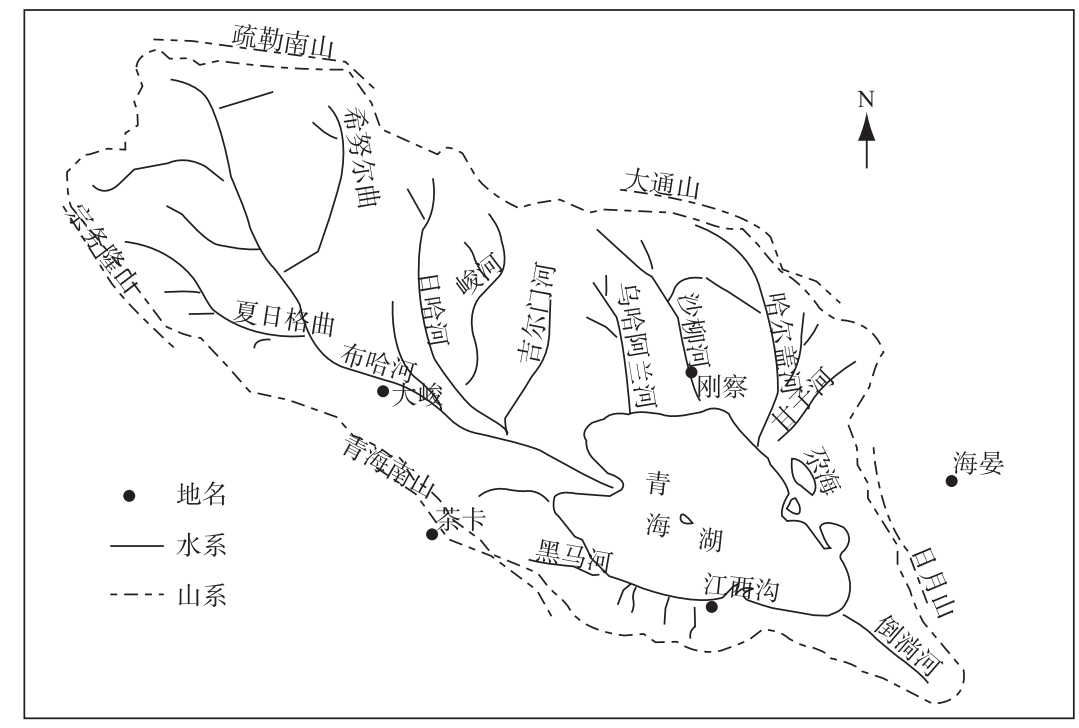

图 1 青海湖流域概况

\section{2 数据资料}

Fig.1 The generalizations of Lake Qinghai basin

本文采用气象数据包括刚察、海晏、茶卡、天峻 4 个气象站 1970-2005 年观测的气温、地温、水汽 压、云量. 部分数据缺测, 进行了数据插补或者弃去不用.

水文数据中的 1959-1999 年青海湖湖面降水量、湖面蒸发量、地表径流量、地下径流量、水位变化 来自《青海湖流域生态环境保护及规划》(图 $2^{\circledR}$ ). 1959-1999 湖面降水量平均为 $359.27 \mathrm{~mm}$, 湖面蒸发量平 均为 $924.59 \mathrm{~mm}$, 地表径流量平均为 $368.12 \mathrm{~mm}$, 地下径流量平均为 $119.38 \mathrm{~mm}$, 水位变化平均为 $-77.82 \mathrm{~mm}$.

(1) 青海省工程咨询中心. 青海湖流域生态环境保护及规划(内部资料). 2001: 15-125. 
1983-2006 年青海湖水温数据由下社水文站观测, 水位数据由沙陀寺和下社水文站观测, 进行了相 应的站点校正.

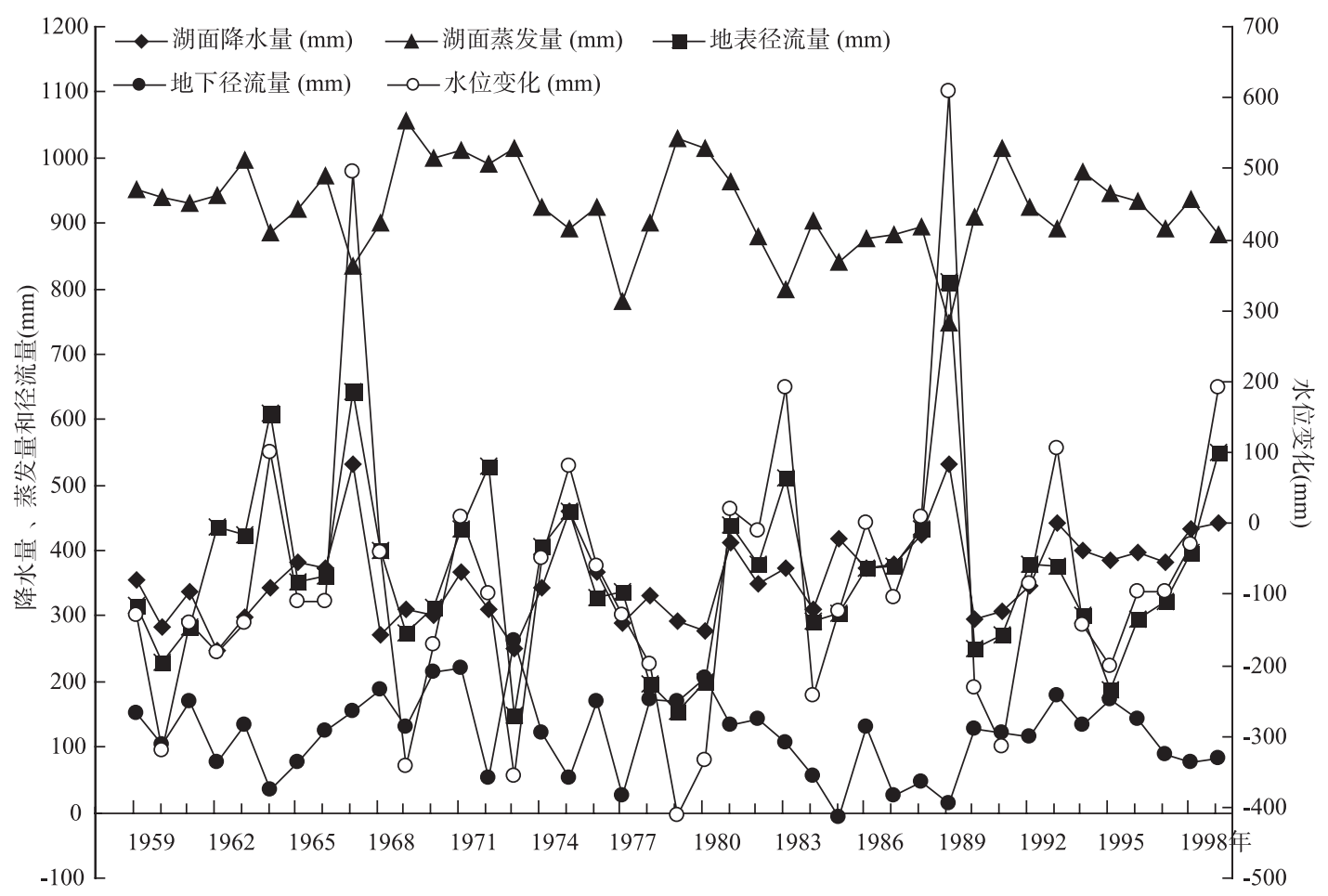

图 2 青海湖湖面降水量、蒸发量、径流量和水位变化(1959-1999 年)

Fig.2 Precipitation, evaporation, runoff and water level in Lake Qinghai (1959-1999)

\section{2 水热平衡模型}

对于青海湖这样的封闭内陆湖流域，如果不考虑下渗、冰雪融水、人类活动等因素影响，全流域基 本符合以下水量平衡方程:

$$
P-E=\Delta H
$$

式中: $P 、 E$ 分别为全流域平均降水量和蒸发量, $\Delta H$ 为湖泊水位变化量. 假如某一时段流域内气候相对稳 定，湖面波动不大，可认为 $\Delta H=0$. 即有:

$$
P=E
$$

也即全流域内降水量与蒸发量相抵, 不存在水量盈亏.上式可进一步展开为:

$$
P_{\mathrm{w}} S_{\mathrm{w}}+P_{1} S_{1}=E_{\mathrm{w}} S_{\mathrm{w}}+E_{1} S_{1}
$$

式中: $P_{\mathrm{w}} 、 P_{1}$ 分别为湖面、流域陆面年平均降水量 $(\mathrm{mm}) ; E_{\mathrm{w}} 、 E_{1}$ 分别为湖面、流域陆面年平均蒸发量 $(\mathrm{mm})$; 此处降水量和蒸发量为陆面或湖面在空间上的平均值, 并不表示流域大范围内降水量和蒸发量保持不变. $S_{\mathrm{w}} 、 S_{1}$ 分别为湖面、流域陆面面积 $\left(\mathrm{km}^{2}\right)$. 当湖泊面积不是太大时, 湖面降水量与流域陆面降水量相差不 大, 我们可以近似地认为, $P_{\mathrm{w}}=P_{1}=P$ 为流域年均降水量 $(\mathrm{mm})$; 引人 $\alpha_{\mathrm{w}}$ 为湖面占全流域面积的百分比, 并 假设流域内陆面降水量和湖面降水量变化不大, 那么(3)式可转化为:

$$
P=E_{\mathrm{w}} \alpha_{\mathrm{w}}+E_{\mathrm{l}}\left(1-\alpha_{\mathrm{w}}\right)
$$

湖面和陆面蒸发量可以通过 Kutzbach ${ }^{[17]}$ 的能量平衡公式计算:

$$
E=R /[(1+B) L]
$$

式中: $R$ 为辐射平衡值 $\left(\mathrm{W} / \mathrm{m}^{2}\right) ; B$ 为波恩比; $L$ 为蒸发潜热, 随温度变化而变化, 但在 $0-30^{\circ} \mathrm{C}$ 之间可取常数 
$0.0769 \mathrm{~W} / \mathrm{m}^{2}$. 净辐射 $R$ 等于净短波辐射 $G$ 与有效长波辐射 $L W$ 之差，即:

$$
R=G(1-\alpha)-L W
$$

式中: $G$ 为实际总辐射 $\left(\mathrm{W} / \mathrm{m}^{2}\right) ; \alpha$ 为下垫面反射率; $L W$ 为有效辐射, 是地表长波辐射与大气逆辐射的差值. 根据钟强研究 ${ }^{[18]}$, 青藏高原地区实际总辐射 $G$ 计算方法为:

$$
G=G_{0}\left[0.285+0.714(1-C)^{0.625}\right]=I K\left[0.285+0.714(1-C)^{0.625}\right]
$$

式中: $I$ 为天文辐射量 $\left(\mathrm{W} / \mathrm{m}^{2}\right) ; K$ 为大气透明系数; $C$ 为云量.

据研究 ${ }^{[19]}$, 有效长波辐射 $L W$ 与地表长波辐射是线性相关的, 可以根据下式计算:

$$
L W=\varepsilon \sigma\left[T_{0}^{4}-T^{4}(0.631+0.2 C+0.0084 e)\right]
$$

式中, $T_{0}$ 和 $T$ 分别为地表温度和气温; $\varepsilon$ 为表面散射率; $\sigma$ 为 Stenfan-Boltzman 常数 $\left(5.67 \times 10^{-8} \mathrm{~W} /\left(\mathrm{m}^{2} \cdot \mathrm{K}^{4}\right)\right) ; C$ 为云量; $e$ 为水汽压.

水面波恩比 $B_{w}$ 根据式(5)计算得出; 陆面波恩比 $B_{1}$ 可用 Kutzbach 在其非线性模型中给出的公式计算 ${ }^{[17]}$ :

$$
B_{1}=\left(R_{1} / L P\right) /\left(1-\mathrm{e}^{-R_{1} /(L P)}\right)-1
$$

式中: $R_{1}$ 为陆地辐射平衡值 $\left(\mathrm{W} / \mathrm{m}^{2}\right), R_{\mathrm{l}} /(L P)=D_{L}, D_{L}$ 为干燥比.

\section{3 水热平衡模型预测青海湖水位变化}

\section{1 温度和降水量预测}

对湖泊未来变化趋势进行预测基本前提是能够对未来流域内气温和降水量的变化做出较为精确的预 测. 丁一汇运用目前世界上比较成熟的气候模式对我国西北各地区 1990-2050 年的气温和降水量变化进 行了预测 ${ }^{[20]}$, 结果经验证是比较可信的. 其对气温和降水自然变化的预测基本依据是太阳活动; 对人类 活动影响下的气温和降水变化的预测则采用中国区域气候模式(NCAR/RegCM). 最终预测结果是自然变 化和人类活动影响下两种结果的算术平均. 本文对青海湖变化趋势的预测便是以此为依据，并通过 1990-2006 年的气象观测数据对前期预测结果进行了验证. 验证发现降水量预测基本准确，气温预测偏 离较大. 所以笔者对气温的预测采用线性回归的方法(图 3), 将刚察、天峻、茶卡 3站 1970-2006 年平均 气温进行算术平均代表青海湖流域年平均气温，线性回归后得到以下方程:

$$
T=0.0373 x-73.864
$$

其中, $T$ 为气温, $x$ 为年份. 方程相关系数 $(R)$ 为 0.677 , 方差解释量 $\left(R^{2}\right)$ 为 0.458 , 调整自由度后 $\left(R^{2}\right.$ adj $)$ 为 $44.2 \%$, 通过了置信度为 0.005 的相关性检验. $F$ 值为 29.57 , 通过了置信度为 0.05 的 $F$ 检验. 根据此方程 计算出 2050 年青海湖流域气温将达到 $2.6^{\circ} \mathrm{C}$, 而丁一汇预测青海省在 2050 年平均气温达到 $3^{\circ} \mathrm{C}$ 左右 ${ }^{[20]}$, 比本文结果稍高.

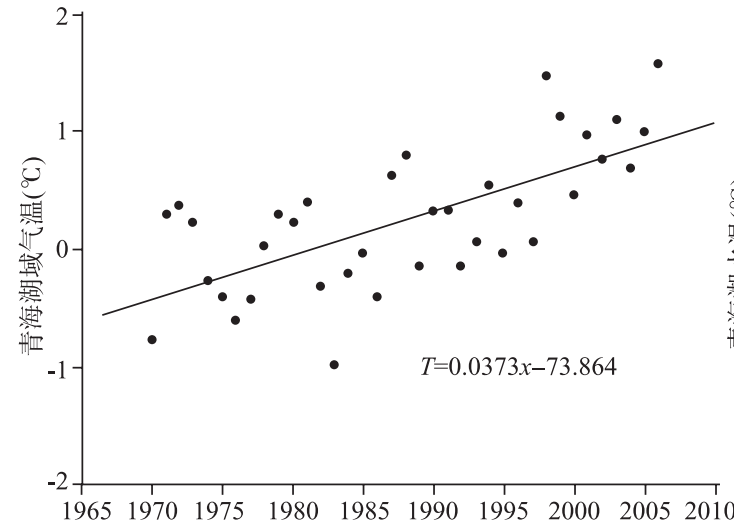

图 3 青海湖流域气温线性拟合

Fig.3 Linear fitting of the Lake Qinghai Basin's temperature

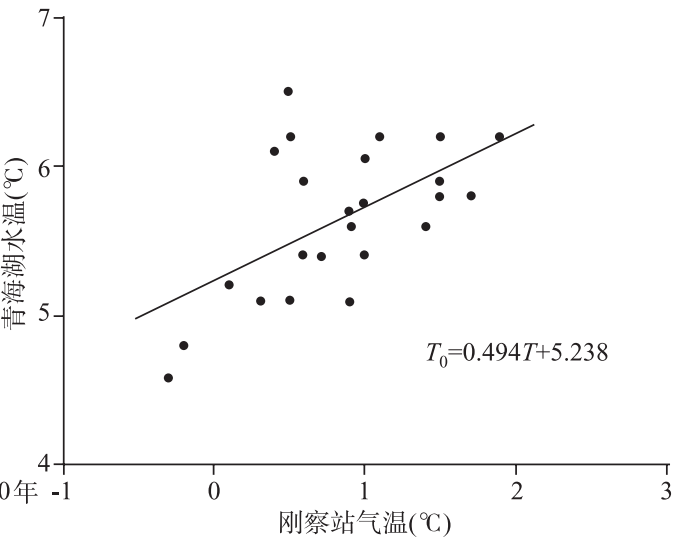

图 4 青海湖水温线性拟合

Fig.4 Linear fitting of the Lake Qinghai's water temperature 
对降水量的预测采用丁一汇 ${ }^{[20]}$ 的结果, 但该书只给出了每隔 20 年的降水量预测值, 我们假设在 20 间降水量是线性变化的，这样可以得到逐年的降水量值.

笔者对 1983-2006 年青海湖水温 $T_{0}$ (下社站)与刚察站气温 $T$ 进行线性回归分析后发现(图 4), 青海湖 水温 $T_{0}$ 可用下式拟合:

$$
T_{0}=0.494 T+5.238
$$

方程相关系数 $(R)$ 为 0.572 , 方差解释量 $\left(R^{2}\right)$ 为 0.328 , 调整自由度后 $\left(R_{\mathrm{adj}}^{2}\right)$ 为 $29.7 \%$, 通过了置信度为 0.005 的相关性检验. $F$ 值为 7.93 , 通过了置信度为 0.05 的 $F$ 检验.

\section{2 湖面蒸发量预测}

对湖面蒸发量的预测采用前面介绍的水热平衡模型，因为本文只用水热平衡模型求算湖面蒸发量而 不求算流域陆面蒸发量, 故湖面参数设置如下:

$I$ 为天文辐射, 1978 年 Berger 给出了现代全球各纬度多年平均天文辐射量(射于大气上界的辐射量 $)^{[21]}$ : 北半球 $40^{\circ} \mathrm{N} 、 30^{\circ} \mathrm{N} 、 20^{\circ} \mathrm{N}$ 分别为: $341.8 、 353.3 、 389.8 \mathrm{~W} / \mathrm{m}^{2}$. 本文中对于青海湖地区天文辐射取值 $37^{\circ} \mathrm{N}$, 即 $345.3 \mathrm{~W} / \mathrm{m}^{2} ; K$ 为大气透明系数, 与纬度位 置以及空气洁净程度有关, 据研究青藏高原 大气透明度比同纬度偏高, 本文确定为 0.78 ; $C$ 为云量, 根据刚察、海晏、茶卡、天峻 4 个气象站 1976-2005 年 30 年观测数据取平 均值求得 $(0.54)$, 在较长一段时期内云量相 对稳定，可以假定未来几十年内云量与现在 相同; $\alpha$ 为反射率, 水面反射率可看作常数 (0.06), 地面反射率因植被覆盖状况不同而 不同, 青海湖流域植被主要为草原、草甸等, 根据相关气候图集确定其反射率为 $0.23 ; \varepsilon$ 为 表面散射率, 水域表面散射率假定为常数 0.96 , 陆地表面散射率根据相关气候图集查 出; $e$ 为水汽压, 假定为现代气象观测的水汽

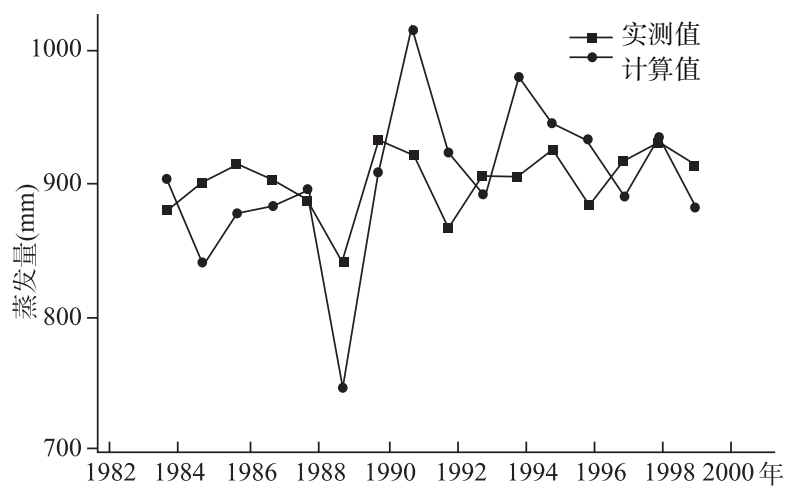

图 5 1984-1999 年青海湖蒸发量预测值与实际值对比 Fig.5 The comparison of the predictive value and observed value of Lake Qinghai's evaporation from 1984 to 1999 压数据. $G_{0}$ 为晴天总辐射, 为 $269.3 \mathrm{~W} / \mathrm{m}^{2}, G$ 为实际总辐射, 为 $194.5 \mathrm{~W} / \mathrm{m}^{2}$. 结合前面对 2050 年以前青海湖流域气温和湖面水温的预测, 通过该模型 估算出 1984-2050 年青海湖湖面蒸发量的逐年值, 并将 1984-1999 年作为校验期，在校验期内模型结果 与实测结果较为拟合(图 5).

\section{3 青海湖水量平衡各要素间关系}

在一个封闭流域内, 水分循环的过程将水量平衡各要素联系在一起. 山区降水通过产流机制形成地 表径流，部分水分深人地下形成地下径流，地表径流和地下径流汇人湖盆，期间伴随着蒸发，地表径流 和地下径流之间也是互相补给的，流域内湖面和陆面蒸发最终又形成水汽. 那么，地表径流量应该是降 水量和蒸发量的函数，而地下径流量应该是降水量、蒸发量和地表径流量的函数. 所以，笔者为了对未来 径流量进行定量估算, 对地表径流量和地下径流量进行了多元线性回归分析.

对 1959-1999 年青海湖地表径流量 $R s$ 与湖面降水量 $P$ 、湖面蒸发量 $E$ 进行了多元线性回归, 发现三 者存在如下关系:

$$
R s=0.739 P+0.099 P_{i-1}-0.840 E+0.599 E_{i-1}+289.983
$$

式中, $P 、 P_{i-1}$ 分别为某年和前一年降水量; $E 、 E_{i-1}$ 分别为某年和前一年湖面蒸发量. 方程(12)的复相关系 数 $R$ 为 0.71 , 拟合效果较好, 并且通过了置信度为 0.005 的 $F$ 检验.

地表径流量与前一年降水量和前一年蒸发量有很好的相关性, 原因是青海湖流域部分河流有一定的 冰雪融水补给, 而上游山区的冰雪积累量与前一年的降水量、蒸发量等因子有关.

通过对 1959-1999 年青海湖地下径流量 $R g$ 与湖面降水量 $P$ 、湖面蒸发量 $E$ 以及地表径流量 $R s$ 进行 
多元线性回归分析, 得到以下方程:

$$
R g=0.157 P_{i-1}-0.032 R s_{i-1}+0.549 E-433.687
$$

式中, $P_{i-1}$ 为前一年降水量; $R s_{i-1}$ 为前一年地表径流量; $E$ 为湖面蒸发量. 方程(13)的复相关系数 $R$ 为 0.57 , 并且也通过了置信度为 0.005 的 $F$ 检验.

\section{4 青海湖水位变化趋势预测}

前面已经提到, 青海湖流域内地表径流量和地下径流量分别与 $P 、 E$ 和 $P 、 E 、 R s$ 存在多元线性回归 的关系, 如式(12)、(13). 根据这两个公式以及预测出的降水量和蒸发量, 我们可以对未来青海湖地表径 流量、地下径流量进行相应的预测.

根据对水量平衡方程各要素做出的预测值, 进一步求出逐年的青海湖水位变化量以及逐年的青海湖 水位. 表 1 给出了未来每隔 10 年青海湖水量平衡各分量的值以及湖泊水位预测值. 1991-2050 年青海湖 水位变化预测结果以及 1990-2005 年青海湖水位实际观测值, 表明模型预测的青海湖水位变化与真实水 位变化拟合得非常好(图 6).

表 12010-2050 年青海湖水量平衡各要素变化趋势预测

Tab.1 Prediction of Lake Qinghai's water balance elements from 2010 to 2050

\begin{tabular}{ccccccc}
\hline 年份 & 气温 $\left({ }^{\circ} \mathrm{C}\right)$ & $\begin{array}{c}\text { 湖面降水 } \\
(\mathrm{mm})\end{array}$ & $\begin{array}{c}\text { 湖面蒸发 } \\
(\mathrm{mm})\end{array}$ & $\begin{array}{c}\text { 地表径流 } \\
(\mathrm{mm})\end{array}$ & $\begin{array}{c}\text { 地下径流 } \\
(\mathrm{mm})\end{array}$ & 水位 $(\mathrm{m})$ \\
\hline 2010 & 1.11 & 413.39 & 966.73 & 401.92 & 149.24 & 3192.80 \\
2020 & 1.48 & 407.29 & 975.24 & 397.72 & 153.67 & 3192.66 \\
2030 & 1.86 & 401.13 & 983.77 & 390.24 & 157.63 & 3192.35 \\
2040 & 2.23 & 394.97 & 992.33 & 382.76 & 161.60 & 3191.87 \\
2050 & 2.6 & 388.82 & 1000.91 & 375.26 & 165.58 & 3191.22 \\
\hline
\end{tabular}

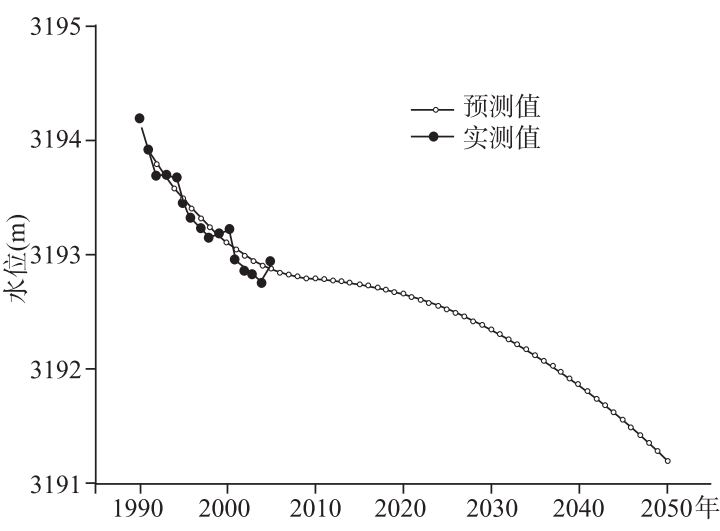

图 6 1990-2050 年青海湖水位变化趋势预测结果

Fig.6 The prediction results of Lake Qinghai's water level variation from 1990 to 2050
1990-2050 年期间，青海湖水位会经历先下 降后稳定再下降的过程: 2020 年以前水位基本稳 定在 $3192.7 \mathrm{~m}$ 左右; 之后水位会继续下降, 2050 年将会下降到 $3191.22 \mathrm{~m}$ (图 6). 总体来说, 未来几 十年内青海湖水位会暂时相对稳定, 停止急剧下 降的趋势, 这可能跟未来西北气候有暖干向暖湿 转型, 引起降水量以及径流量增加有关. 但是随 着气候持续增暖导致蒸发量继续增加，当青海湖 人湖补给量总体上不能抵消水量支出也即湖面蒸 发量时, 水位会继续下降.

\section{4 结论及讨论}

根据水热平衡模型预测, 2020 年以前青海湖 水位将保持相对稳定，水位约波动在 $3192.7 \mathrm{~m}$; 之后水位会继续下降，且下降速度呈加快趋势， 到 2050 年水位下降至 $3191.22 \mathrm{~m}$ 左右. 前期青海湖水量达到相对平衡, 可能跟西北气候向暖湿转型、降 水量增加有关; 后期水位继续较快下降可能是因为随着气温持续上升, 蒸发量不断增加, 而降水量增加 的趋势有所减缓(表 1)导致的. 在一定的气候背景下人类活动影响较小时, 水位的升降是由流域气温和降 水的不同变化幅度和组合关系决定的, 所以青海湖水位在 2020 年前后下降速度开始加快也体现了区域 气候情景发生变化.

近些年来，青海湖水位曾出现几次短暂回升，很多人预言青海湖水位将由下降转为上升. 青海湖水位 
上升的情况自 1959 年以来已经多次出现, 但都仅持续了 1-2 年, 之后水位仍是继续下降. 水位上升年份 分别是 1964、1967、1971、1975、1981、1983、1988、1989、1993、1999、2000、2005 年(图 2). 这应 是降水量或蒸发量的突然性变化改变湖泊水量平衡引起的, 并不代表长期内青海湖水位的变化趋势. 1959-2005 年青海湖水位一直是在波动中下降的，这并不与本文预测结果相冲突(图 6). 总体来说, 未来 几十年内，青海湖水位的下降趋势将有所缓和，这必将有利于青海湖流域生态环境的保护和恢复. 但同 时应看到, 2030 年以后青海湖水位仍有可能快速下降, 甚至有干涸的危险. 届时青海湖流域生态环境将 发生严重退化, 并对当地居民生活生产造成不良影响, 应引起相关部门的足够重视.

本文虽然运用水热平衡的方法对青海湖未来一段时期内的水位进行了定量的预测, 但在模型参数设 置上仍有许多不合理的地方, 如假定辐射状况、反射率等保持不变, 会引起一定的误差. 而且模型预测精 度直接取决于未来温度和降水情景的预测，这两个基本气候因子预测的不确定性会导致模型预测结果并 不一定准确, 还需要更加深人的研究来提高预测精度.

致谢: 青海省水文局和青海省气象局对本文提供了数据支持, 两位匿名审稿人对本文提出了宝贵的修改 意见, 兰州大学资源环境学院李育、李国栋和候迎同学对本文提出许多建设性的意见, 在论文完成过程 中还得到了多位同窗及好友的大力帮助，在此一并致谢.

\section{5 参考文献}

[1] 李标梁, 魏 丽, 蔡 英等. 中国西北现代气候变化事实与未来趋势展望. 冰川冻土, 2003, 25(2): 135-142.

[2] 高华中, 贾玉连. 西北典型内陆湖泊近 40 年来的演化特点及机制分析. 干旱区资源与环境, 2005, 19(5): 93-96.

[3] 郭 铌, 张 杰, 梁 芸. 西北地区近年来内陆湖泊变化反映的气候问题. 冰川冻土, 2003, 2(2): 211-214.

[4] 江钟葵, 李晓辉. 青海湖近 20 年水域变化及湖岸演变遥感监测研究. 古地理学报, 2006, 8(1): 131-141.

[5] 王 润, Ernst Giese, 高前兆. 近期博斯腾湖水位变化及其原因分析. 冰川冻土, 2003, 25(1): 60-64.

[6] Wunnemann B, Pachur HJ, Zhang H. Climate and environment changes in the deserts of Inner Mongolia, China, since late Pleistocene. In: Alsharhan AS ed. Quaternary desert and climate. Rotterdam: Balkema, 1998: 381-394.

[7] 于 革, 赖格英, 薛 滨等. 中国西部湖泊水量对未来气候变化的响应. 湖泊科学, 2004, 16(3): 193-202.

[8] 施雅风, 沈永平, 胡汝骥. 西北气候由暖干向暖湿转型的信号、影响和前景初步探讨. 冰川冻土, 2002, 24(3): 219-226.

[9] 施雅风, 沈永平, 李栋梁等. 中国西北气候由暖干向暖湿转型的特征和趋势探讨. 第四纪研究, 2003, 23(2): 152-164.

[10] 申洪源, 贾玉连, 魏 灵. 未次冰期间冰阶(40-22 kaBP)内蒙古黄旗海古降水量研究. 沉积学报, 2005, 23(3): 523-530.

[11] 贾玉连, 王苏民, 吴艳宏等. 24kaB.P. 以来青藏高原中部湖泊演化及古降水量研究——兹格塘错与错鄂为例. 海洋与湖 沼, 2003, 34(3): 283-294.

[12] 赵 强, 李秀梅, 王乃昂. 6700-5800 yr BP 期间石羊河流域的水量平衡. 干旱区资源与环境, 2007, 21(6): 84-91.

[13] 邵兆刚, 孟宪刚, 朱大岗等. 西藏纳木错晚更新世以来古降水量变化及其环境响应. 地质力学学报, 2004, 10(4): $337-343$.

[14] 王黎军. 青海湖水位下降的成因分析与对策. 青海大学学报(自然科学版), 2003, 21(5): 28-31.

[15] 郭 武. 青海湖水位下降与湖区生态环境演变研究. 干旱区资源与环境, 1997, 11(2): 75-80.

[16] 朱 琰, 崔广柏, 杨 理. 青海湖萎缩干涸原因、发展趋势及对生态环境的影响. 河海大学学报, 2001, 29(4): 104-108.

[17] Kutzbach JE. Estimates of past climate at Paleolake Chad, North Africa, based on hydrological and energy-balance model. Quaternary Research, 1980, 14: 47-82.

[18] 钟 强. 青藏高原太阳总辐射的计算方法的讨论. 高原气象, 1986, 5(3): 197-210.

[19] 章基嘉, 朱抱真, 朱福康等. 青藏高原气象学进展——青藏高原气象科学实验(1979)和研究. 北京: 科学出版社, 1988.

[20] 丁一汇. 中国西部环境演变评估(第二卷): 中国西部环境变化的预测. 北京: 科学出版社, 2002: 157.

[21] Berger A. Long-term variations of caloric resulting from the Earth's orbital elements. Quaternary Research, 1978, 9: 139-167. 